\title{
Brain Region-Specific nAChR and Associated Protein Abundance Alterations Following Chronic Nicotine and/or Menthol Exposure
}

\author{
Matthew J. Mulcahy ${ }^{\star}{ }^{\dagger}$, Stephanie M. Huard ${ }^{\dagger}$, Joao A. Paulo ${ }^{\ddagger}$, Jonathan H. Wang ${ }^{\dagger}$, Sheri \\ McKinney $^{\dagger}$, Brandon J. Henderson ${ }^{\dagger} \S$, Henry A. Lester ${ }^{\dagger}$ \\ † Division of Biology and Biological Engineering, California Institute of Technology, 1200 East \\ California Boulevard, Pasadena, California 91125-2900, United States \\ ‡ Department of Cell Biology, Harvard Medical School, 240 Longwood Avenue, Boston, \\ Massachusetts 02115, United States \\ $\S$ Department of Biomedical Sciences, Joan C. Edwards School of Medicine, Marshall University, \\ Huntington, West Virginia 25701, United States
}

\begin{abstract}
The identification of biomarkers that are altered following nicotine/tobacco exposure can facilitate the investigation of tobacco-related diseases. Nicotinic acetylcholine receptors (nAChRs) are pentameric cation channels expressed in the mammalian central and peripheral nervous systems and the neuromuscular junction. Neuronal nAChR subunits (11) have been identified in mammals $(a 2-7, a 9-10, \beta 2-4)$. We examined changes in $\beta 2 \mathrm{nAChR}$ subunit protein levels after chronic nicotine, $( \pm)$-menthol, or nicotine co-administered with $( \pm)$-menthol in nine murine brain regions. Our investigation of $\beta 2 \mathrm{nAChR}$ subunit level changes identified the hypothalamus as a novel region of interest for menthol exposure that demonstrated increased $\beta 2 \mathrm{nAChR}$ levels after $( \pm)$ menthol plus nicotine exposure compared to nicotine exposure alone. Using mass spectrometry, we further characterized changes in membrane protein abundance profiles in the hypothalamus to identify potential biomarkers of $( \pm)$-menthol plus nicotine exposure and proteins that may contribute to the elevated $\beta 2 \mathrm{nAChR}$ subunit levels. In the hypothalamus, 272 membrane proteins were identified with altered abundances after chronic nicotine plus menthol exposure with respect to chronic nicotine exposure without menthol. A comprehensive investigation of changes in
\end{abstract}

\footnotetext{
*Corresponding Author: mmulcahy@ caltech.edu. Phone: 626-395-4932.

Author Contributions

The manuscript was written through the contributions of all authors. All authors have given approval to the final version of the manuscript. M.J.M., S.M.H., J.A.P., B.J.H., and H.A.L. conceived and designed experiments. M.J.M., S.M.H., and J.A.P. performed the experiments. J.A.P., J.H.W., and S.M. contributed reagents/materials/analysis tools. M.J.M. wrote the manuscript. M.J.M., S.M.H., J.A.P., B.J.H., and H.A.L. edited the manuscript.

The authors declare no competing financial interest.

The mass spectrometry proteomics data have been deposited to the PRIDE Archive (http://www.ebi.ac.uk/pride/archive/) via the PRIDE partner repository with the data set identifier PXD012244. ${ }^{69}$

Supporting Information

The Supporting Information is available free of charge on the ACS Publications website at DOI: 10.1021/acs.jproteome.9b00286. Distribution of changes for all proteins identified in ( \pm )-menthol plus nicotine-exposed samples (Table S-1); $\beta 2$ immunoblot validation (Figure S-1); vehicle-normalized nicotine alone altered proteins (Table S-2); vehicle-normalized ( \pm )-menthol plus nicotine-altered proteins (Table S-3); all proteins identified in ( \pm )-menthol plus nicotine-exposed samples (Table S-4) (XLSX)
} 
$\mathrm{nAChR}$ and non-nAChR protein expression resulting from ( \pm )-menthol plus nicotine in the brain may establish biomarkers to better understand the effects of these drugs on addiction and addiction-related diseases.

\section{Graphical Abstract}

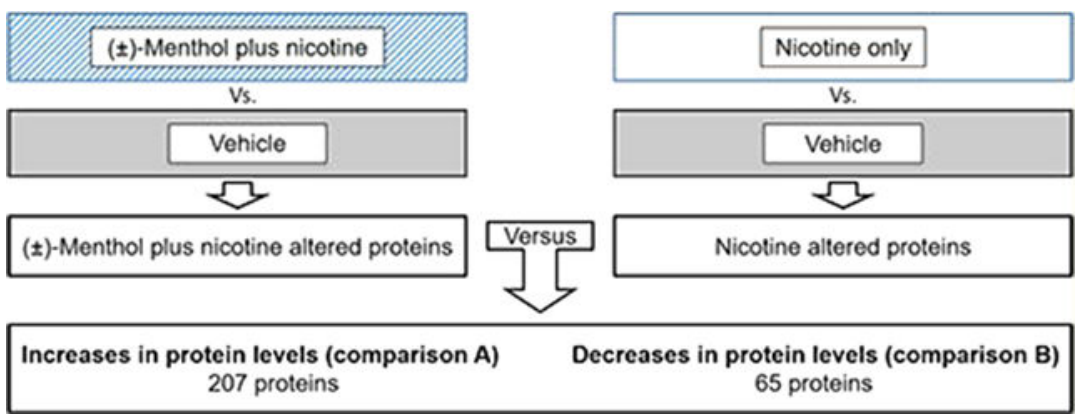

\section{Keywords}

$\beta 2 \mathrm{nAChR}$ subunit; nicotine; menthol; immunoblotting; mass spectrometry; addiction

\section{INTRODUCTION}

Chronic exposure to nicotine and other tobacco product additives alters protein levels that may contribute to tobacco-related diseases. A key requisite in defining the effects of tobacco products and their additives is the identification of markers of exposure. Nicotine, the addictive compound in tobacco products, binds to and activates nicotinic acetylcholine receptors (nAChRs). nAChRs are pentameric cation channels expressed in the mammalian central (CNS) and peripheral (PNS) nervous systems as well as in skeletal muscle. Neuronal nAChR subunits (11) have been identified in mammals $(\alpha 2-7, a 9-10, \beta 2-4)$, and the most prevalent mammalian CNS nAChRs contain $a 4 \beta 2, a 3 \beta 4$, and $a 7$ subunits. ${ }^{1}$

In 1985, reports first showed that some nAChRs increase in number and in sensitivity to nicotine during chronic nicotine exposure. ${ }^{2,3}$ This upregulation of nAChRs following nicotine/tobacco exposure displays selectivity regarding brain region, neuron type, somatodendritic versus axonal regions, and nAChR subtype. ${ }^{4-8}$ A key concept is that upregulation can occur due to post-translational steps. Through "inside-out pharmacology", nicotine can act as a pharmacological chaperone to facilitate trafficking of nascent nAChRs in the endoplasmic reticulum (ER) and enhance nAChR levels on the plasma membrane. ${ }^{9}$ Several groups are pursuing the hypothesis that upregulation is both necessary and sufficient for the early stages of nicotine dependence. Therefore, the quantification of changes in protein levels (e.g., nAChR subunits) has the potential to become a mechanistically revealing marker for chronic nicotine/tobacco exposure.

Menthol is a common flavoring found in tobacco products that are used by a third of all smokers. ${ }^{10}$ The number of known protein biomarkers for exposure to nicotine/tobacco products, as well as product additives such as menthol, is limited. Protein markers of nicotine exposure, such as nAChR levels, are useful for several reasons. First, although 
small-molecule markers for nicotine exposure, such as the major nicotine metabolite cotinine, are useful for tracking tobacco product/nicotine exposure, they do not offer insight into proteomic changes that may contribute to tobacco-related diseases. Second, we can gain insight into the biological response to nicotine exposure by investigating altered levels (increases and/or decreases) of proteins associated with various functions or processes after chronic nicotine exposure. The identification of protein changes in key brain regions linked to addiction may be of interest for a better understanding of addiction or for the identification of therapeutic targets.

This study reports on the combined use of immunoblotting and mass spectrometry to characterize changes in protein levels in response to chronic nicotine, $( \pm)$-menthol, and $( \pm)$ menthol plus nicotine in specific brain regions (Figure 1). We first established changes in $\mathrm{nAChR}$ subunit levels in response to chronic nicotine, $( \pm)$-menthol, and ( \pm )-menthol plus nicotine using immunoblotting. We then characterized changes in total membrane-bound protein levels in the hypothalamus using mass spectrometry. Together, these approaches evaluated nAChR subunit expression as a biomarker of chronic nicotine, ( \pm )-menthol, and $( \pm)$-menthol plus nicotine exposure in specific brain regions and identified a collection of non-nAChR protein markers of chronic nicotine and $( \pm)$-menthol plus nicotine exposure in the hypothalamus.

The goal of this work was to identify potential nAChR (e.g., $\beta 2 \mathrm{nAChR}$ subunit levels) and non-nAChR protein biomarkers of interest following chronic nicotine, $( \pm)$-menthol, and $( \pm)$ menthol plus nicotine exposure. Proteins of interest are those that have altered expression in response to chronic nicotine exposure versus vehicle as well as chronic ( \pm )-menthol coadministered with nicotine versus nicotine exposure alone. The identified biomarkers of exposure reported here are potentially beneficial for monitoring both mentholated and nonmentholated tobacco product use and may help identify possible effects that menthol itself elicits on protein expression.

\section{METHODS}

\section{Drug Administration Using Osmotic Minipumps}

All procedures were conducted in accordance with National Institutes of Health guidelines for care and use of animals, and protocols were approved by the Institutional Animal Care and Use Committee at the California Institute of Technology (protocol 1386-13G). Male C57/B16 mice 3-6 months of age were used. Racemic menthol, i.e., ( \pm )-menthol, is a 50/50 mixture of (+)-menthol and (-)-menthol stereoisomers. The selected methods of nicotine, $( \pm)$-menthol, and $( \pm)$-menthol plus nicotine delivery and dose were established and described previously. ${ }^{11,12}$ In brief, osmotic minipumps (Alzet) were implanted under the skin for 12 days to deliver vehicle (60\% ethanol, $40 \%$ water), nicotine $[2 \mathrm{mg} /(\mathrm{kg} \mathrm{h})],( \pm)$-menthol [2 $\mathrm{mg} /(\mathrm{kg} \mathrm{h})]$, or $( \pm)$-menthol plus nicotine [both $2 \mathrm{mg} /(\mathrm{kg} \mathrm{h})]$.

\section{Mouse Brain Tissue Collection and Dissection}

Brains of male C57B1/6 wild-type, $a 4 \mathrm{nAChR}$ knockout, or $\beta 2 \mathrm{nAChR}$ knockout mice were isolated and immediately dissected on ice. For brain region-specific analyses, brains were 
serially dissected to isolate specific brain regions. All tissues were frozen at $-80^{\circ} \mathrm{C}$ immediately after dissection.

\section{Mouse Brain Membrane Protein Solubilization}

Dissected mouse brain regions were homogenized in $50 \mathrm{mM} \mathrm{NaCl}, 50 \mathrm{mM} \mathrm{NaH}{ }_{2} \mathrm{PO}_{4}, 2 \mathrm{mM}$ ethylenediaminetetraacetic acid (EDTA), $2 \mathrm{mM}$ ethylene glycol-bis( $\beta$-aminoethyl ether)$\mathrm{N}, \mathrm{N}, \mathrm{N}^{\prime}, \mathrm{N}^{\prime}$-tetraacetic acid (EGTA), pH 7.4, with 30 strokes of a Potter-Elvehjem glass homogenizer or disposable polypropylene pestles on ice. Membrane fragments were isolated following centrifugation at $21130 \mathrm{~g}$ for $10 \mathrm{~min}$ at $4{ }^{\circ} \mathrm{C}$. Membrane pellets were then homogenized in the previous buffer with the addition of $2 \%$ Triton X-100 with 40 strokes of a Potter-Elvehjem glass homogenizer or disposable polypropylene pestles and incubated for $3 \mathrm{~h}$ at $4{ }^{\circ} \mathrm{C}$ with agitation to solubilize membrane-bound proteins. Following second centrifugation at $21130 \mathrm{~g}$ for $10 \mathrm{~min}$ at $4{ }^{\circ} \mathrm{C}$, the solubilized membrane fraction was recovered in the supernatant. All buffers used to isolate the solubilized membrane fraction were supplemented with protease inhibitors (Cell Signaling Technology, www.cellsignal.com). The protein content of solubilized membrane fractions was determined using a bicinchoninic assay (Pierce Biotechnology, www.thermofisher.com).

\section{Immunoblotting}

Detergent-solubilized membrane preparations from each dissected brain region were analyzed using immunoblots. Samples were incubated at $95^{\circ} \mathrm{C}$ for $5 \mathrm{~min}$ in $1 \times$ Laemmli sample buffer and $355 \mathrm{nM} \beta$-mercaptoethanol (Bio-Rad, Hercules, CA, www.bio-rad.com) to reduce disulfide bonds. The $\mathrm{pH}$ of each sample was adjusted with $1 \mathrm{M}$ Tris base and alkylated using $100 \mathrm{mM}$ iodoacetamide at room temperature for $1 \mathrm{~h}$ in the dark. Proteins were separated by sodium dodecyl sulfate-polyacrylamide gel electrophoresis ( $3 \mu \mathrm{g}$ protein per lane) and transferred to Immun-Blot low fluorescence poly(vinylidene difluoride) membranes (Bio-Rad). For ndufa1 immunoblots, membranes were incubated with REVERT (Li-Cor, Lincoln, NE, www.licor.com) total protein stain according to the manufacturer's protocol prior to blocking. Membranes were blocked using Odyssey Tris-buffered saline (TBS) blocking buffer ( $\mathrm{Li}-\mathrm{Cor})$ for $1 \mathrm{~h}$ at room temperature $\left(20-25^{\circ} \mathrm{C}\right)$. Membranes were incubated with anti- $\beta 2 \mathrm{nAChR}$ subunit antibodies (1:100, SC1449, Santa Cruz, Dallas, TX, www.scbt.com) and anti-glyceraldehyde 3-phosphate dehydrogenase (anti-GAPDH) antibodies (1:1000, Ab9485, Abcam, Cambridge, U.K., www.abcam.com) or antindufa1 antibodies (1:400, Ab131423, Abcam). All antibodies were diluted in Odyssey TBS blocking buffer supplemented with $0.1 \%$ Tween-20 ("antibody buffer") overnight at $4{ }^{\circ} \mathrm{C}$. After washing, the membrane was incubated with anti-goat secondary antibodies (1:5 000, 926-68074, Li-Cor) and anti-rabbit secondary antibodies (1:10 000, 926-32213, Li-Cor) in antibody buffer. The membrane was then washed, and targeted proteins were visualized using an Odyssey scanner (Li-Cor).

\section{Immunoblotting (Menthol alone Experiments Only)}

For menthol alone experiments, immunoblotting was performed as described above with the following differences. Per lane, $6 \mu \mathrm{g}$ of solubilized protein was loaded rather than $3 \mu \mathrm{g}$. For blocking, $5 \%$ milk in TBS was used. Anti- $\beta 2$ nAChR (1:100, SC1449, Santa Cruz) and antiGAPDH antibodies (1:2500, Ab9485, Abcam) were diluted in TBS plus 3\% milk and $0.1 \%$ 
Tween-20 buffer overnight at $4{ }^{\circ} \mathrm{C}$. After primary incubation, membranes were washed and incubated with anti-goat secondary antibodies (1:5000, A21084, ThermoFisher Scientific, San Jose, CA, www.thermofisher.com) and anti-rabbit secondary antibodies (1:15 000, 92632213, Li-Cor) diluted in TBS plus 3\% milk. Membranes were then washed and visualized, as described above.

\section{Immunoblotting Data Analysis}

A biological replicate for each drug treatment was measured in triplicate or quadruplicate on the same gel. Band-integrated intensities were quantified using the Li-Cor Odyssey Application Software (version 3.0, Li-Cor). All $\beta 2$ immunoreactivity signals were normalized to GAPDH. Observed $\beta 2$ immunoreactivity was quantified as changes in the signal from the vehicle. A Student's $t$-test (one-tailed, two-sample equal variance) was used to statistically confirm changes. For biomarker validation studies, three biological replicate samples for each condition were evaluated in duplicate for each gel. Each validation was repeated with a second immunoblot with randomized sample location. Band-integrated intensities were quantified using the Li-Cor Odyssey Image Studio (version 5.2, Li-Cor). All target immunoreactivity signals were normalized to REVERT (Li-Cor) total protein stain. Observed ndufa1 immunoreactivity for nicotine alone and ( \pm )-menthol plus nicotine was quantified as a change in signal from vehicle. A Student's $t$-test (one-tailed, two-sample equal variance) was used to identify statistical significance.

\section{Mass Spectrometry Sample Preparation and In-Solution Trypsin Digestion}

To prepare for mass spectrometric analysis, $100 \mu \mathrm{g}$ of protein samples was thawed and disulfide/sulfhydryl residues were reduced with $50 \mathrm{mM}$ tris(2-carboxyethyl)phosphine (TCEP) in $20 \mathrm{mM} \mathrm{N}$-(2-hydroxyethyl)piperazine- $\mathrm{N}^{\prime}$-ethanesulfonic acid (HEPES), $\mathrm{pH} 8.0$ for $1 \mathrm{~h}$ at $60^{\circ} \mathrm{C}$. Samples were alkylated with $100 \mathrm{mM}$ iodoacetamide in $20 \mathrm{mM}$ HEPES, pH 8.0 for $1 \mathrm{~h}$ in the dark at room temperature $\left(20-25^{\circ} \mathrm{C}\right)$. Samples were then concentrated and purified via precipitation using a ReadyPrep 2-D Cleanup Kit (Bio-Rad). Precipitated protein was resuspended in $50 \mathrm{mM}$ ammonium bicarbonate, $\mathrm{pH} 7.8$, supplemented with 100 ng of trypsin (Promega, Madison, WI, www.promega.com) and digested overnight insolution at $37{ }^{\circ} \mathrm{C}$. Following digestion, samples were dried and stored at $-20^{\circ} \mathrm{C}$ until analysis.

\section{Tandem Mass Tag (TMT) Labeling}

TMT labeling and subsequent mass spectrometry analysis were performed using the SLTMT sample process strategy. ${ }^{13}$ Briefly, TMT reagents $(0.8 \mathrm{mg})$ were dissolved in anhydrous acetonitrile (ACN, $40 \mu \mathrm{L}$ ) of which $10 \mu \mathrm{L}$ was added to the peptides (100 $\mu \mathrm{g}$ ) along with $30 \mu \mathrm{L}$ of acetonitrile to achieve a final acetonitrile concentration of approximately $30 \%(\mathrm{v} / \mathrm{v})$. Following incubation at room temperature for $1 \mathrm{~h}$, the reaction was quenched with hydroxylamine to a final concentration of $0.3 \%(\mathrm{v} / \mathrm{v})$. We mixed $5 \%$ of each sample and analyzed the ratios among reporter ions. As such, we performed a global normalization within each TMT by ensuring that the samples were pooled at a 1:1 ratio across all channels. The sample was vacuum-centrifuged to near dryness and subjected to C18 solid-phase extraction (Sep-Pak, Waters). 


\section{Basic pH Reversed-Phase (BPRP) Fractionation Allowed for Deep Proteome Analysis}

A total of $100 \mu \mathrm{g}$ of the peptide from each of the channels was combined, desalted, and fractionated with basic $\mathrm{pH}$ reversed-phase (BPRP) chromatography. Following desalting, peptides were resuspended in buffer $\mathrm{A}(10 \mathrm{mM}$ ammonium bicarbonate, $5 \% \mathrm{ACN}, \mathrm{pH} 8)$ and loaded onto an Agilent 300Extend C18 column (5 $\mu \mathrm{m}$ particles, $4.6 \mathrm{~mm}$ ID, and $220 \mathrm{~mm}$ in length). The peptide mixture was fractionated with a 60 min linear gradient from 0 to $42 \%$ buffer B (10 mM ammonium bicarbonate, $90 \% \mathrm{ACN}, \mathrm{pH} 8)$. A total of 96 fractions was collected and concatenated so that every 24th fraction was pooled (i.e., samples in wells A1, $\mathrm{C} 1, \mathrm{E} 1$, and G1 were combined) and only alternating pooled fractions (a total of 12) were analyzed. ${ }^{14}$

\section{Liquid Chromatography and Tandem Mass Spectrometry (LC-MS/MS)}

The samples were reconstituted in 5\% acetonitrile and 5\% formic acid for LC-MS/MS processing. Peptides were separated on a $35 \mathrm{~cm}$ long, $100 \mu \mathrm{m}$ inner diameter microcapillary column packed with Accucore $(2.6 \mu \mathrm{m}, 150 \AA$ ) $)$ resin (Thermo Fisher Scientific). For each analysis, we loaded $0.5 \mu \mathrm{g}$ of the sample onto the $\mathrm{C} 18$ capillary column using a Proxeon NanoLC-1200 UHPLC. Peptides were separated in-line with the mass spectrometer using gradients of 6-26\% acetonitrile in $0.125 \%$ formic acid at a flow rate of $\sim 500 \mathrm{~nL} / \mathrm{min}$. Data were collected using the SPS-MS3 method on an Orbitrap Fusion Lumos mass spectrometer (Thermo Fisher Scientific). Peptides were separated using a 150 min gradient of 3-25\% acetonitrile in $0.125 \%$ formic acid with a flow rate of $450 \mathrm{~nL} / \mathrm{min}$. Each analysis used an MS3-based TMT method, ${ }^{15,16}$ which has been shown to reduce ion interference compared to MS2 quantification. ${ }^{17}$ Prior to starting our analysis, we performed two injections of trifluoroethanol to elute any peptides that may have been bound to the analytical column from prior injections to limit carry over. The scan sequence began with an MS1 spectrum [Orbitrap analysis, resolution 120 000, 350-1400 Th, automatic gain control (AGC) target 5 $\times 10^{5}$, maximum injection time $100 \mathrm{~ms}$ ]. The top 10 precursors were then selected for the MS2/MS3 analysis. MS2 analysis consisted of collision-induced dissociation, quadrupole ion trap analysis, automatic gain control (AGC) $1.8 \times 10^{4}$, normalized collision energy (NCE) 35, $q$-value 0.25 , maximum injection time $120 \mathrm{~ms}$, and isolation window at 0.7 . Following the acquisition of each MS2 spectrum, we collected an MS3 spectrum in which multiple MS2 fragment ions are captured in the MS3 precursor population using isolation waveforms with multiple frequency notches. MS3 precursors were fragmented by HCD and analyzed using the Orbitrap (NCE 65, AGC $1.5 \times 10^{5}$, maximum injection time $150 \mathrm{~ms}$, the resolution was 50000 at $400 \mathrm{Th}$ ). For MS3 analysis, we used charge state-dependent isolation windows: for charge state $z=2$, the isolation window was set at $1.3 \mathrm{Th}$, for $z=3$ at $1 \mathrm{Th}$, for $z=4$ at $0.8 \mathrm{Th}$, and for $z=5$ at $0.7 \mathrm{Th}$.

\section{Database Searching and TMT Quantification Analysis}

Mass spectra were processed using a SEQUEST-based software pipeline. ${ }^{18}$ Database searching included all entries from the Uniprot mouse database (March 20, 2016). This database was concatenated with one composed of all protein sequences in the reversed order. Searches were performed using a $50 \mathrm{ppm}$ precursor ion tolerance. The product ion tolerance was set to $0.9 \mathrm{Da}$. These wide mass tolerance windows were chosen to maximize sensitivity 
in conjunction with SEQUEST searches and linear discriminant analysis. ${ }^{18,19}$ TMT tags on lysine residues and peptide $\mathrm{N}$ termini (+229.163 Da) and carbamidomethylation of cysteine residues $(+57.021 \mathrm{Da})$ were set as static modifications, while oxidation of methionine residues $(+15.995 \mathrm{Da})$ was set as a variable modification.

Peptide-spectrum matches (PSMs) were adjusted to a $1 \%$ false discovery rate (FDR). ${ }^{20,21}$ PSM filtering was performed using a linear discriminant analysis, as described previously, ${ }^{18}$ while considering the following parameters: XCorr, $\Delta \mathrm{Cn}$, missed cleavages, peptide length, charge state, and precursor mass accuracy. For TMT-based reporter ion quantitation, we extracted the signal-to-noise $(\mathrm{S} / \mathrm{N})$ ratio for each TMT channel and found the closest matching centroid to the expected mass of the TMT reporter ion. PSMs were identified, quantified, and collapsed to a $1 \%$ peptide false discovery rate (FDR) and then collapsed further to a final protein level FDR of $1 \%$. Moreover, protein assembly was guided by principles of parsimony to produce the smallest set of proteins necessary to account for all observed peptides.

Peptide intensities were quantified by summing reporter ion counts across all matching PSMs so as to give greater weight to more intense ions. ${ }^{16,22}$ PSMs with poor quality, MS3 spectra with TMT reporter summed signal-to-noise measurements that were less than 100, or with no MS3 spectra were excluded from quantitation. Isolation specificity of $\geq 0.7$ (i.e., peptide purity $>70 \%$ ) was required. ${ }^{22}$

\section{Post-Search Data Analysis}

Hypothalami treated with each of the three conditions were analyzed with six biological replicates (18 total samples). Samples were split into two groups of nine for TMT labeling and analysis, with each group of nine containing three vehicle, three nicotine alone, and three $( \pm)$-menthol plus nicotine samples. Nicotine and $( \pm)$-menthol plus nicotine sample TMT signals were normalized to average vehicle TMT signals within each TMT set. Statistical significance between vehicle-normalized $( \pm)$-menthol plus nicotine and nicotine alone values was determined using a Student's $t$-test. Search tool for the retrieval of interacting genes/proteins (STRING, v. 11, https://string-db.org/) was used to visualize hypothalamic proteomes and to illustrate known connections between identified interacting proteins. ${ }^{23}$ All statistically significant protein level differences were evaluated to identify protein enrichments for biological processes (GO terms) or pathways (KEGG pathway analysis or Reactome pathway analysis). For consideration as a potential biomarker for ( \pm )menthol plus nicotine exposure, target proteins were required to be statistically different from both vehicle and nicotine alone treatments and to have altered levels in the 97.5th percentile or 2.5 th percentile per data set (i.e., the largest $5 \%$ of observed protein level changes) (Table S-1). 


\section{RESULTS AND DISCUSSION}

\section{Quantification of $\beta 2$ Subunit Levels in Selected Mouse Brain Regions after Exposure to Chronic Nicotine, ( \pm )-Menthol, or ( \pm )-Menthol Plus Nicotine Exposure}

Prior to region-specific analysis of $\beta 2 \mathrm{nAChR}$ subunit levels in response to drug treatments, the specificity of the $\beta 2$ antibody used was verified against both $a 4$ and $\beta 2 \mathrm{nAChR}$ subunit knockout whole brain samples. It has been shown previously that deleting $a 4$ subunit expression also diminishes $\beta 2 \mathrm{nAChR}$ subunit expression in most brain regions. ${ }^{24}$ Immunoreactivity for the $\beta 2$ antibody in both knockout tissues was $<1 \%$ of the immunoreactivity observed in wild-type whole brain samples (Figures 2A and S-1). Following confirmation of antibody specificity, we investigated dissected brain regions for changes in $\beta 2$ immunoreactivity levels after chronic drug treatments.

Initial investigations measured $\beta 2 \mathrm{nAChR}$ subunit levels in response to chronic $( \pm)$-menthol alone in five brain regions: cortex, hypothalamus, midbrain, olfactory tubercles, and thalamus. Of the five regions, only one, the hypothalamus, displayed a statistically significant $(p=0.03)$ increase in $\beta 2 \mathrm{nAChR}$ subunit levels in response to chronic $( \pm)$ menthol alone (Figure 2B).

Subsequent immunoblotting compared chronic nicotine and ( \pm )-menthol plus nicotine exposure versus the vehicle. Several minor modifications were made to the immunoblotting protocol to reduce background fluorescence and to improve sensitivity (see Methods section). Nine brain regions were investigated: the cerebellum, cortex, hindbrain, hippocampus, hypothalamus, midbrain, olfactory tubercles, thalamus, and striatum. All investigated regions, except the hypothalamus (10.7\% increase in mean, p-value 0.09), demonstrated increased $\beta 2 \mathrm{nAChR}$ subunit levels in response to nicotine alone (Figure 2C). Two brain regions, the cortex and the hypothalamus, were shown to have increased $\beta 2$ nAChR subunit levels comparing ( \pm )-menthol plus nicotine to nicotine alone (Figure $2 \mathrm{C}$ ). The hypothalamus, which has not been previously shown to be affected by menthol exposure, was selected for further analysis using mass spectrometry to identify proteins that could contribute to the elevated $\beta 2 \mathrm{nAChR}$ subunit levels as well as potential biomarkers of $( \pm)$-menthol plus nicotine exposure.

\section{Changes in Membrane-Bound Protein Levels in the Hypothalamus Were Investigated Using Mass Spectrometry}

Quantifying protein level changes between the drug treatments has the potential to reveal (1) possible biomarkers for menthol exposure, (2) proteins contributing to the increase in nAChR levels seen following nicotine and ( \pm )-menthol plus nicotine exposure, and (3) elucidate the effects of menthol on the hypothalamus specifically. Two proteomes were identified in the hypothalamus: a nicotine-altered proteome and a ( \pm )-menthol plus nicotinealtered proteome (Tables S-2 and S-3). Each of the two proteomes was characterized by normalizing tandem mass tag (TMT) values from nicotine and ( \pm )-menthol plus nicotine, respectively, to vehicle values. The comparison of vehicle-normalized ( \pm )-menthol plus nicotine and nicotine alone signals identified proteins that had upregulated (comparison A), downregulated (comparison B), or unaltered levels when menthol was present (Table S-4). 
Comparison A identified 207 upregulated proteins and comparison B identified 65 downregulated proteins when $( \pm)$-menthol was present (Figure 3C).

We performed network-based analysis using STRING for proteins demonstrating significantly altered abundance profiles (refer to Methods section). For each comparison, the distribution of percent changes between the compared groups was plotted and the proteins in the 97.5th (\% increase in levels) percentile and the bottom 2.5th (\% decrease in levels) percentile, representing the top 5\% of protein level changes, were investigated. Proteins (2645) were identified in 5/6 or 6/6 replicates in hypothalamic samples chronically treated with ( \pm )-menthol plus nicotine compared to nicotine alone. The top $5 \%$ of altered protein levels of these 2645 proteins identified, included 59 potential biomarkers (Table 1). These proteins can be considered as candidates for hypothalamic markers of mentholated cigarette smoke exposure [ $( \pm)$-menthol plus nicotine] compared to traditional cigarette (nicotine alone) smoke exposure. One of these potential biomarkers, ndufa1, was further validated with immunoblots (Figure 4).

\section{Identifying Changes in nAChR Subunit Levels Adds Important Information beyond mRNA Levels, Receptor Levels, and Functional Assessments}

Each level of expression (mRNA, protein, assembled receptor) and receptor function may be affected differently following chronic nicotine and $( \pm)$-menthol plus nicotine exposure. Studies that characterized changes (or lack of changes) in mRNA or receptor levels in specific brain regions in response to chronic nicotine have been published. ${ }^{5,25}$ No comprehensive (i.e., more than three brain regions) investigation of $\beta 2 \mathrm{nAChR}$ subunit levels in response to chronic nicotine has been published. ${ }^{4,26}$

Although several independent groups have reported changes in $\mathrm{nAChR}$ levels in one or several brain regions, the majority of analyses report changes in $\beta 2 * \mathrm{nAChR}$ number and not changes in $\beta 2 \mathrm{nAChR}$ subunit levels. It must not be assumed that subunit levels, assembled receptor levels, and surface-expressed receptor levels are regulated in the same manner in response to chronic drug treatments. For example, nAChR mRNA levels elevate in Alzheimer's disease, while protein levels decrease. Changes in one level of expression may reflect compensation for deficits in another. ${ }^{27}$ For the first time, we systematically measured changes in $\beta 2 \mathrm{nAChR}$ subunit levels in response to chronic drug treatments in nine brain regions, establishing $\beta 2 \mathrm{nAChR}$ subunit levels as a tool for assessing exposure to nicotine and $( \pm)$-menthol plus nicotine in specific brain regions.

We evaluated if $\beta 2 \mathrm{nAChR}$ subunit levels could be used as a biomarker of chronic ( \pm )menthol plus nicotine exposure. $a 4$ and $\beta 2 \mathrm{nAChR}$ subunits are the most abundant in the mammalian central nervous system. Changes in $\beta 2 \mathrm{nAChR}$ subunit levels were chosen as a potential biomarker over other $\mathrm{nAChR}$ subunits (e.g., a4) for the following reasons. The first reason for selecting $\beta 2 \mathrm{nAChR}$ subunit levels is that $\beta 2$ may assemble into $\mathrm{nAChRs}$ with subunits other than $a 4$. Although not abundant in all brain regions, non- $a 4 \beta 2, \beta 2 * \mathrm{nAChRs}$ (i.e., $\beta 2$-containing nAChRs) are expressed in the habenula and interpeduncular nucleus. ${ }^{24}$ Furthermore, non- $a 4 \beta 2, \beta 2 *$ nAChRs may also be more abundant in peripheral tissues such as the blood. Leukocytes have been shown to express "neuronal" nAChRs and blood cells 
may be an advantageous model for studying nAChRs and biomarkers as the blood is more easily obtained than brain tissue. ${ }^{28}$

A previous study used positron emission tomography scanning with the radioligand 2- $\left[{ }^{18} \mathrm{~F}\right]$ fluoro-A-85380 and showed that human smokers of mentholated cigarettes have increased levels of $\beta 2 * \mathrm{nAChRs}$ in the brainstem, cerebellum, and corpus callosum but not the prefrontal cortex compared to nonmenthol smokers. ${ }^{29}$ In mouse models, subunit level increases of $\beta 2 \mathrm{nAChR}$ subunits in the murine hippocampus, striatum, and prefrontal cortex in response to chronic nicotine [administered continuously via osmotic minipump, $2 \mathrm{mg} /(\mathrm{kg}$ h) for 10 days], chronic (-)-menthol (administered once a day via intraperitoneal injection, $100 \mathrm{mg} / \mathrm{kg}$ for 10 days), or chronic (-)-menthol plus nicotine were previously reported. ${ }^{4}$ This study found that $a 4$ levels increased in response to chronic nicotine alone in the striatum and increased in response to chronic (-)-menthol alone in the striatum and prefrontal cortex. Levels of $\beta 2$ subunits increased in response to chronic nicotine alone as well as in response to chronic (-)-menthol alone in all three regions. Compared to nicotine alone, Alsharari et al. showed that chronic (-)-menthol plus nicotine demonstrated increases in both $a 4$ and $\beta 2$ only in the cortex. ${ }^{4}$ Upregulation of fluorescent $a 4^{*}$ and $a 4 a 6^{*} \mathrm{nAChRs}$ (by knock-in mice expressing nAChRs with fluorescent tags) was observed in ventral tegmental area neurons of the midbrain after menthol plus nicotine exposure [both administered by osmotic minipump, $2 \mathrm{mg} /(\mathrm{kg} \mathrm{h})$ for 10 days or nicotine administered by osmotic minipump, $2 \mathrm{mg} /(\mathrm{kg} \mathrm{h})$ and menthol administered by alternating 8 day injections, 1 $\mathrm{mg} / \mathrm{kg}] .^{12}$ Although previous studies showed that $( \pm)$-menthol alone changes surface nAChR levels and alters physiology, the published information on total subunit or receptor level changes in multiple brain regions is limited.

\section{This Study Is the First To Investigate Exposure of Hypothalamus to Either Nicotine or ( \pm )- Menthol Plus Nicotine at the Global Proteome Level}

We focused on characterizing the effects of nicotine and menthol co-exposure, as this condition is the most relevant application of menthol in mentholated cigarettes. In this work, we directly paired continuous chronic nicotine and chronic menthol exposure using osmotic minipumps and expanded the scope of analysis to investigate nine brain regions for changes in $\beta 2$ subunit levels. We identified the hypothalamus as a novel region of interest for menthol exposure that demonstrated increased $\beta 2 \mathrm{nAChR}$ levels after ( \pm )-menthol compared to vehicle and after $( \pm)$-menthol plus nicotine exposure compared to nicotine exposure alone. We further characterized protein level changes after chronic exposure to nicotine or $( \pm)$-menthol plus nicotine in the hypothalamus.

We studied racemic rather than (-)-menthol. Our previous studies demonstrated a functional effect of ( \pm )-menthol (administered in the same way as described in this study) on nAChRs in dopaminergic neurons of the midbrain. ${ }^{12}$ Although (-)-menthol is the naturally occurring isomer and is thought to be more biologically active (e.g., activation of TRPM8), synthetic menthol is often added to tobacco products; the stereochemical composition of menthol in tobacco products is neither disclosed nor regulated at present. The method by which menthol enhances tobacco product usage is, in part, thought to be through anti-inflammatory and/or analgesic effects. ${ }^{30,31}$ In the lungs and mouth, which both express TRPM8, this is a 
convincing argument. However, in the brain, where TRPM8 is not highly expressed, the specificity of the (-)-menthol on TRPM8 channels is less relevant. Additionally, several non-TRPM8 channels, such as TRPA1 and TRPV1, are inhibited rather than activated by acute exposure to menthol. ${ }^{32-35}$

In a previous study demonstrating that menthol exposure alters nAChR function, the dopaminergic neurons studied did not express TRPM8, suggesting that the effect of menthol was through another target. ${ }^{12}$ Relevant to the present study, the human hypothalamus does not have RNA expression for TRPM8. ${ }^{36}$ Similarly, there is very little TRPM8 RNA levels compared to other transient receptor potential (TRP) channels such as TRPV2 and TRPA1 in the rodent hypothalamus. ${ }^{37}$ These previous studies also demonstrate that TRP channels other than TRPM8 are expressed in regions that have shown responses to menthol and may be of interest. Several studies do show protein level data in the hypothalamus using immunoblotting, but at very low levels in mice without cold stress and none use TRPM8 knockout controls for their immunoassays.

We identified two TRP channels, TRPM3 and TRPV2, by mass spectrometry in the hypothalamus. TRPM8 was not identified in any of the observed proteomes or comparisons. Non-TRP channel targets for menthol were also identified, including $\mathrm{GABA}_{\mathrm{A}}$ receptor subunits (Gabra1, Gabrb1, Gabrg2, Gabrg3) and $\kappa$ opioid receptors (Oprk1). Menthol is a positive allosteric modulator of $\mathrm{GABA}_{\mathrm{A}}$ receptors and a weak agonist of the $\kappa$ opioid receptor (Table 2). ${ }^{38}$ Of these identified menthol targets, Gabrg2 and TRPV2 had decreased levels comparing ( \pm )-menthol plus nicotine compared to nicotine alone. Until the target(s) in the brain have been positively identified, it cannot be assumed that the pharmacologically more active (-)-menthol at the TRPM8 receptor is relevant. We have previously reported that the different stereoisomers have different effects on $a 4 \beta 2 \mathrm{nAChR}$ function. ${ }^{39}$ Based on these prior reports and the findings in this study, future studies should separately investigate changes in protein levels after (-)-menthol and (+)-menthol exposure as two relevant compounds in tobacco products.

\section{Altered Proteins in the Hypothalamus Have a Potential Influence on Addiction}

The hypothalamus participates in several neuroendocrine systems that mediate biological processes, such as immune responses and stress. Nicotine activates the hypothalamicpituitary-adrenal (HPA) axis. ${ }^{40,50}$ Nicotine stimulation of the paraventricular nucleus (PVN) of the hypothalamus leads to the secretion of corticotropin-releasing hormone (CRH), which, in turn, leads to the secretion of adrenocorticotropic hormone (ACTH) from the pituitary gland. ACTH release leads to the secretion of cortisol, a key stress hormone. ${ }^{41}$ Chronic stress is involved with several addiction-related behaviors, such as increased vulnerability to drug use, drug self-administration, and relapse. ${ }^{40}$

Smokers have elevated cortisol levels compared to non-smokers and have reduced elevations of cortisol levels in response to stress. ${ }^{41-43}$ Changes in cortisol secretion levels after smoking cessation may also predict the likelihood of relapse. ${ }^{42}$ Former smokers with persistently elevated cortisol levels after smoking cessation are more likely to relapse when presented with stress. ${ }^{44}$ The connection between the HPA axis, addiction, and smoking 
cessation makes understanding how chronic nicotine and chronic menthol plus nicotine affect the HPA axis of extreme interest for identification of possible therapeutic targets.

Previous reports have used mass spectrometry to describe effects of chronic nicotine exposure on protein levels in specific brain regions (e.g., whole brain, cortex, and hippocampus) and non-neuronal tissue (e.g., heart, kidney, liver, lung, pancreas, and spleen) but not the hypothalamus. ${ }^{45-48}$ In this study, we identified hypothalamic protein level changes and we characterized the pathways and ontologies of altered proteins after chronic nicotine or $( \pm)$-menthol plus nicotine exposure to give insight into the effects of exposure to these drugs.

Before considering the general and hypothalamic specific impact of menthol, we first considered nicotine exposure alone. An increase in $a 4$ and $\beta 2 \mathrm{nAChR}$ subunits was identified using mass spectrometry in the nicotine-altered proteome (Table S-2). No other nAChR subunits were detectably changed. Several pathways known to be affected by chronic nicotine and to contribute to $\mathrm{nAChR}$ expression were enriched in the identified set of nicotine-altered proteins (Table 3). Several of these enriched pathways are involved with the trafficking of proteins within and between the ER and Golgi, possibly contributing to the "inside-out pharmacology" of nicotine. ${ }^{9}$

In addition to $\mathrm{nAChR}$ upregulation, chronic nicotine exposure alters the function of several endocrine pathways, including the release of CRH, as noted above. Several pathways can regulate $\mathrm{CRH}$ release from the hypothalamus and lead to changes in the HPA axis.

Cholinergic, GABAergic, glutamatergic, and serotonergic signals can all modulate CRH release. ${ }^{49}$ Local hypothalamic release of dopamine from mesocortical and tuberoinfundibular pathways can also regulate the HPA axis. ${ }^{51,52}$ The chronic nicotine proteome has enrichments for several neurotransmitter pathways. The enrichment for proteins involved with "transmission across chemical synapses" after chronic nicotine, a pathway which includes cholinergic (e.g., Chrnb2) and GABAergic (e.g., Gabbr1, Gabrb1, and Gabrg2) proteins, was of particular interest.

\section{We Expand upon Previous Studies That Demonstrated a Functional Effect of ( \pm )-Menthol on nAChRs in Dopaminergic Neurons of the Midbrain}

We investigated five brain regions in our studies of ( \pm )-menthol alone: the cortex, hypothalamus, midbrain, olfactory tubercles, and thalamus. Although the cortex, midbrain, olfactory tubercles, and thalamus did not exhibit an effect on $\beta 2 \mathrm{nAChR}$ subunit levels in response to chronic menthol, the hypothalamus did demonstrate an increase in $\beta 2 \mathrm{nAChR}$ subunit levels. We note that ( \pm )-menthol alone had no effect on $\beta 2$ subunit levels in the cortex, in contrast to previous reports. ${ }^{4}$ This discrepancy may be due to differences in menthol preparations [(-)-menthol versus ( \pm )-menthol] or differences in administration (noncontinuous menthol plus continuous nicotine exposure versus continuous menthol plus continuous nicotine exposure in our study). Resolution of this discrepancy requires further comparisons of menthol administration and dosing.

Nicotine alone elicited an increase in $\beta 2 \mathrm{nAChR}$ subunit levels in most brain regions investigated but not in the hypothalamus (p-value 0.09). The effects of chronic nicotine have 
been investigated in the hypothalamus previously using epibatidine binding or autoradiography techniques, which measure receptors or surface-expressed subunits, though not with $\beta 2$ immunoblots or solubilized extracts. ${ }^{5,53}$ The upregulation of assembled nAChRs or surface-expressed nAChRs in the hypothalamus may, therefore, reflect a change in protein expression after subunit synthesis. Alternatively, the nicotine-elicited increase of $\beta 2 \mathrm{nAChR}$ subunit levels in the hypothalamus is the smallest observed (10.7\%) $\beta 2$ subunit increase and may, therefore, not be a large enough difference to be distinguished from the vehicle-treated control using immunoblotting.

Fewer brain regions showed elevated $\beta 2 \mathrm{nAChR}$ subunit levels in response to chronic $( \pm)$ menthol plus nicotine compared to nicotine alone. In agreement with Alsharari et al., our findings show that the cortex demonstrated an increase in $\beta 2$ subunit levels when menthol was co-administered with nicotine compared to nicotine exposure alone. Interestingly, the hypothalamus, which was the only investigated brain region to show a response to $( \pm)$ menthol alone, also demonstrated an increase in $\beta 2 \mathrm{nAChR}$ subunit levels with ( \pm )-menthol plus nicotine compared to nicotine alone (Figure 2B,C). A recent report determined that menthol binds to $a 4 \beta 2 \mathrm{nAChRs}$ within the transmembrane region. ${ }^{39}$ However, it is unclear if this region-specific upregulation in response to chronic menthol or ( \pm )-menthol plus nicotine exposure is through direct or indirect interaction of menthol with nAChRs. We analyzed the hypothalamic membrane preparations used in the immunoblotting assays using mass spectrometry to identify region-specific protein level changes, which could shed light on the region-specific nature of the effects of menthol on protein levels in the hypothalamus.

\section{Identifying Protein Level Alterations after Menthol Exposure Facilitates Studies on the Impact of Mentholated Cigarettes on the Hypothalamus}

Quantifying menthol-sensitive alterations in proteins levels may identify possible biomarkers of ( \pm )-menthol plus nicotine exposure and highlight how menthol affects the HPA axis, connecting the endocrine system to the study of menthol and addiction.

In this study, we profiled nicotine-altered proteins (nicotine versus vehicle) and ( \pm )-menthol plus nicotine proteins $[( \pm)$-menthol plus nicotine versus vehicle]. The nicotine-altered proteome contains 1115 proteins and the $( \pm)$-menthol plus nicotine-altered proteome includes 734 proteins. By comparing these two proteomes, we can identify proteins that are altered with the administration of menthol. Two comparisons were made when analyzing differences between nicotine-altered and $( \pm)$-menthol plus nicotine proteins in the hypothalamus. The first comparison (comparison A) identified proteins with increased levels after ( \pm )-menthol plus nicotine. The second comparison (comparison B) identified proteins with decreased levels comparing ( \pm )-menthol plus nicotine to nicotine-exposed values. Although an increase in $\beta 2$ and $a 4 \mathrm{nAChR}$ subunits was identified in the ( \pm )-menthol plus nicotine-altered proteome, the increase was not great enough to meet inclusion criteria for comparison A (Table S-4).

Henderson et al. hypothesized that, like nicotine, menthol-mediated upregulation of nAChR levels involves cycling of nAChRs between the Golgi and endoplasmic reticulum (ER). ${ }^{12}$ To investigate possible proteins of interest that may be related to $\mathrm{nAChR}$ upregulation, we 
examined changes in levels of membrane proteins in response to $( \pm)$-menthol plus nicotine versus nicotine exposure.

A total of 207 upregulation proteins were identified when comparing changes observed in $( \pm)$-menthol plus nicotine samples to nicotine samples (comparison A). STRING analysis of comparison A proteins shows enrichments for both membrane trafficking and posttranslational protein modification. More specifically, enriched processes include ER to Golgi vesicle-mediated transport, Golgi vesicle transport, post-Golgi vesicle-mediated transport, and Golgi to plasma membrane protein transport (Figure 5). These data suggest that menthol can increase the protein levels of proteins associated with various stages of nAChR expression from levels in mice chronically treated with nicotine. Additionally, the enrichment of ER and Golgi protein transport processes are consistent with the Henderson et al. 2016 hypothesis that ER to Golgi cycling may be crucial for the effects of menthol on $\mathrm{nAChR}$ protein levels. Although the nicotine-exposed proteome had enrichments for proteins associated with the endocrine system, the $( \pm)$-menthol plus nicotine-exposed proteome did not.

Comparison B identified proteins that were downregulated comparing ( \pm )-menthol plus nicotine to nicotine alone (Table S-4). A total of 65 proteins was identified in comparison B with enrichments in pathways that include complex 1 biogenesis as well as the biological processes of mitochondrial adenosine $55^{\prime}$-triphosphate (ATP) synthesis-coupled electron transport, mitochondrion organization, and mitochondrial transport. Many of these proteins had increased levels in the nicotine-exposed proteome but no change in levels in the ( \pm )menthol plus nicotine proteome. Nicotine exposure alone has been shown to upregulate or downregulate mitochondria electron-transport system proteins in a brain region-specific manner as well as reduce reactive oxygen species (ROS) levels, specifically through complex I. ${ }^{54-56}$ Menthol cigarette smoke extracts also affect ROS generation differently than nonmenthol cigarette smoke extracts in lung tissue and menthol exposure, independent of TRPM8, elevates ROS generation in cell lines through modulation of $\mathrm{Ca}^{2+}$ release. ${ }^{57,58}$ ROS levels also regulate several hypothalamic processes, including energy metabolism, body weight, and HPA axis activation. ${ }^{59-61}$ The menthol-mediated changes in complex I protein levels observed in this study could lead to altered ROS levels in the hypothalamus, which, in turn, could affect HPA axis signaling, impacting downstream behaviors such as stress and addiction.

Seven proteins of mitochondrial electron-transport chain complex I were identified in comparison B: mtnd4, ndufa1, ndufa6, ndufc2, ndufs2, ndufs5, and ndufs4. These seven proteins also constituted proteins with the greatest changes (all decreases) in levels comparing exposure to $( \pm)$-menthol plus nicotine and exposure to nicotine alone in either comparison A or B (Figure 6). Ndufa1, an accessory subunit of mitochondrial electrontransport chain complex 1, was selected for validation as a potential biomarker for differentiating exposure to $( \pm)$-menthol plus nicotine and exposure to nicotine alone. Changes in response to chronic nicotine and ( \pm )-menthol plus nicotine compared to nicotine for ndufa1 were confirmed by immunoblotting, validating ndufa 1 as a potential biomarker for menthol exposure (Figure 4). 
Numerous studies show that menthol participates in the initiation of smoking and increased difficulty in smoking cessation for mentholated cigarette smokers when compared to nonmentholated cigarette smokers. ${ }^{12,30,62,63}$ The hypotheses for these phenomena have included reduction of inflammation in the lungs, effects on $\mathrm{nAChR}$ function in reward pathways, or modification of the metabolism of nicotine. ${ }^{4}$ The data presented here introduce a novel hypothesis that proteomic changes in the hypothalamus, such as changes in nAChR or mitochondrial complex I protein levels, may contribute to the effects of menthol. The hypothalamus had increased $\beta 2 \mathrm{nAChR}$ subunit levels after both chronic menthol exposure compared to the vehicle as well as after chronic ( \pm )-menthol plus nicotine compared to nicotine alone.

\section{CONCLUSIONS}

Nicotine exposure is a pressing public health issue due to its known roles in tobacco-related diseases. Tobacco research would benefit from the identification of proteins with altered levels following nicotine exposure and from understanding their functions. Additionally, although nicotine is the primary addictive agent in tobacco products, other components, such as menthol, may impact levels, location, and function of proteins of interest for the study of addiction or tobacco product regulation. ${ }^{64-68}$

We report, for the first time, a comprehensive investigation of $\beta 2 \mathrm{nAChR}$ subunit levels in nine murine brain regions following chronic nicotine and $( \pm)$-menthol plus nicotine exposure and in five brain regions for ( \pm )-menthol alone. The hypothalamus was the only region identified that had elevated $\beta 2 \mathrm{nAChR}$ subunit levels after chronic ( \pm )-menthol treatment as well as elevated $\beta 2 \mathrm{nAChR}$ subunit levels with ( \pm )-menthol plus nicotine treatment compared to both vehicle and nicotine alone. Understanding how changes in $\beta 2 \mathrm{nAChR}$ levels occur may, therefore, be useful in understanding how users are affected by exposure to ( \pm )-menthol alone (e.g., vaping menthol e-liquids), nicotine (e.g., traditional cigarettes), and $( \pm)$-menthol plus nicotine (e.g., mentholated cigarettes). We used mass spectrometry to characterize further changes in membrane protein levels in the hypothalamus to identify potential biomarkers of $( \pm)$-menthol plus nicotine exposure as well as identify possible proteins that contribute to the elevated $\beta 2 \mathrm{nAChR}$ subunit levels. Mitochondrial electrontransport chain complex I was identified as a potential key target for menthol exposure in the hypothalamus. Ndufa1, an accessory subunit of the mitochondrial electron-transport chain complex 1 , was validated as a potential biomarker for comparing $( \pm)$-menthol plus nicotine exposure and nicotine exposure. The region-specific protein changes in the hypothalamus, a key member of the HPA axis, suggest that menthol could play a role in addiction through effects on stress.

The identification of changes in $\beta 2 \mathrm{nAChR}$ subunit levels after chronic nicotine, ( \pm )menthol, or $( \pm)$-menthol plus nicotine exposure will enhance our understanding of the biochemical changes that occur in response to exposure to these drugs in different brain regions. The proteins identified in the hypothalamus contribute to the understanding of biochemical changes involved with stress and addiction as well as identify potential therapeutic targets for the management of addiction and smoking cessation. 


\title{
Supplementary Material
}

Refer to Web version on PubMed Central for supplementary material.

\section{ACKNOWLEDGMENTS}

\author{
We also thank Dr. Steven P. Gygi and the Taplin Mass Spectrometry Facility at Harvard Medical School for use of \\ their mass spectrometers and access to their Sequest-based data analysis suite. \\ Funding \\ This research was supported by NIH R01DA036061 (H.A.L.) and R01GM132129 (J.A.P.).
}

\section{ABBREVIATIONS}

GAPDH glyceraldehyde 3-phosphate dehydrogenase

KEGG Kyoto Encyclopedia of Genes and Genomes

nAChR nicotinic acetylcholine receptor

STRING search tool for the retrieval of interacting genes/proteins

HPA hypothalamic-pituitary-adrenal

\section{REFERENCES}

(1). Albuquerque EX; Pereira EF; Alkondon M; Rogers SW Mammalian nicotinic acetylcholine receptors: from structure to function. Physiol. Rev. 2009, 89, 73-120. [PubMed: 19126755]

(2). Marks MJ; Stitzel JA; Collins AC Time course study of the effects of chronic nicotine infusion on drug response and brain receptors. J. Pharmacol. Exp. Ther. 1985, 235, 619-628. [PubMed: 4078726]

(3). Schwartz RD; Kellar KJ In vivo regulation of ${ }^{3}$ Hacetylcholine recognition sites in brain by nicotinic cholinergic drugs. J. Neurochem. 1985, 45, 427-433. [PubMed: 4009168]

(4). Alsharari SD; King JR; Nordman JC; Muldoon PP; Jackson A; Zhu AZ; Tyndale RF; Kabbani N; Damaj MI Effects of Menthol on Nicotine Pharmacokinetic, Pharmacology and Dependence in Mice. PLoS One 2015, 10, No. e0137070. [PubMed: 26355604]

(5). Marks MJ; McClure-Begley TD; Whiteaker P; Salminen O; Brown RW; Cooper J; Collins AC; Lindstrom JM Increased nicotinic acetylcholine receptor protein underlies chronic nicotineinduced up-regulation of nicotinic agonist binding sites in mouse brain. J. Pharmacol. Exp. Ther. 2011, 337, 187-200. [PubMed: 21228066]

(6). Perry DC; Davila-Garcia MI; Stockmeier CA; Kellar KJ Increased nicotinic receptors in brains from smokers: membrane binding and autoradiography studies. J. Pharmacol. Exp. Ther. 1999, 289, 1545-1552. [PubMed: 10336551]

(7). Breese CR; Marks MJ; Logel J; Adams CE; Sullivan B; Collins AC; Leonard S Effect of smoking history on $\left[{ }^{3} \mathrm{H}\right]$ nicotine binding in human postmortem brain. J. Pharmacol. Exp. Ther. 1997, 282, 7-13. [PubMed: 9223534]

(8). Peng X; Gerzanich V; Anand R; Wang F; Lindstrom J Chronic nicotine treatment up-regulates a3 and $a 7$ acetylcholine receptor subtypes expressed by the human neuroblastoma cell line SHSY5Y. Mol. Pharmacol. 1997, 51, 776-784. [PubMed: 9145915]

(9). Henderson BJ; Lester HA Inside-out neuropharmacology of nicotinic drugs. Neuropharmacology 2015, 96, 178-193. [PubMed: 25660637]

(10). McCarthy WJ; Caskey NH; Jarvik ME; Gross TM; Rosenblatt MR; Carpenter C Menthol vs nonmenthol cigarettes: effects on smoking behavior. Am. J. Public Health 1995, 85, 67-72. [PubMed: 7832264] 
(11). Henderson BJ; Srinivasan R; Nichols WA; Dilworth CN; Gutierrez DF; Mackey ED; McKinney $\mathrm{S}$; Drenan RM; Richards CI; Lester HA Nicotine exploits a COPI-mediated process for chaperone-mediated up-regulation of its receptors. J. Gen. Physiol. 2014, 143, 51-66. [PubMed: 24378908]

(12). Henderson BJ; Wall TR; Henley BM; Kim CH; Nichols WA; Moaddel R; Xiao C; Lester HA Menthol Alone Upregulates Midbrain nAChRs, Alters nAChR Subtype Stoichiometry, Alters Dopamine Neuron Firing Frequency, and Prevents Nicotine Reward. J. Neurosci. 2016, 36, 2957-2974. [PubMed: 26961950]

(13). Navarrete-Perea J; Yu Q; Gygi SP; Paulo JA Streamlined Tandem Mass Tag (SL-TMT) Protocol: An Efficient Strategy for Quantitative (Phospho)proteome Profiling Using Tandem Mass TagSynchronous Precursor Selection-MS3. J. Proteome Res. 2018, 17, 2226-2236. [PubMed: 29734811]

(14). Paulo JA; O’Connell JD; Everley RA; O’Brien J; Gygi MA; Gygi SP Quantitative mass spectrometry-based multiplexing compares the abundance of $5000 \mathrm{~S}$. cerevisiae proteins across 10 carbon sources. J. Proteomics 2016, 148, 85-93. [PubMed: 27432472]

(15). Ting L; Rad R; Gygi SP; Haas W MS3 eliminates ratio distortion in isobaric multiplexed quantitative proteomics. Nat. Methods 2011, 8, 937-940. [PubMed: 21963607]

(16). McAlister GC; Nusinow DP; Jedrychowski MP; Wuhr M; Huttlin EL; Erickson BK; Rad R; Haas W; Gygi SP MultiNotch MS3 enables accurate, sensitive, and multiplexed detection of differential expression across cancer cell line proteomes. Anal. Chem. 2014, 86, 7150-7158. [PubMed: 24927332]

(17). Paulo JA; O’Connell JD; Gygi SP A Triple Knockout (TKO) Proteomics Standard for Diagnosing Ion Interference in Isobaric Labeling Experiments. J. Am. Soc. Mass Spectrom. 2016, 27, 16201625. [PubMed: 27400695]

(18). Huttlin EL; Jedrychowski MP; Elias JE; Goswami T; Rad R; Beausoleil SA; Villen J; Haas W; Sowa ME; Gygi SP A tissue-specific atlas of mouse protein phosphorylation and expression. Cell 2010, 143, 1174-1189. [PubMed: 21183079]

(19). Beausoleil SA; Villen J; Gerber SA; Rush J; Gygi SP A probability-based approach for highthroughput protein phosphorylation analysis and site localization. Nat. Biotechnol. 2006, 24, 1285-1292. [PubMed: 16964243]

(20). Elias JE; Gygi SP Target-decoy search strategy for mass spectrometry-based proteomics. Methods Mol. Biol. 2010, 604, 55-71. [PubMed: 20013364]

(21). Elias JE; Gygi SP Target-decoy search strategy for increased confidence in large-scale protein identifications by mass spectrometry. Nat. Methods 2007, 4, 207-214. [PubMed: 17327847]

(22). McAlister GC; Huttlin EL; Haas W; Ting L; Jedrychowski MP; Rogers JC; Kuhn K; Pike I; Grothe RA; Blethrow JD; Gygi SP Increasing the multiplexing capacity of TMTs using reporter ion isotopologues with isobaric masses. Anal. Chem. 2012, 84, 7469-7478. [PubMed: 22880955]

(23). Szklarczyk D; Franceschini A; Wyder S; Forslund K; Heller D; Huerta-Cepas J; Simonovic M; Roth A; Santos A; Tsafou KP; Kuhn M; Bork P; Jensen LJ; von Mering C STRING v10: proteinprotein interaction networks, integrated over the tree of life. Nucleic Acids Res. 2015, 43, D447D452. [PubMed: 25352553]

(24). Whiteaker P; Cooper JF; Salminen O; Marks MJ; McClure-Begley TD; Brown RW; Collins AC; Lindstrom JM Immunolabeling demonstrates the interdependence of mouse brain $a 4$ and $\beta 2$ nicotinic acetylcholine receptor subunit expression. J. Comp. Neurol. 2006, 499, 1016-1038. [PubMed: 17072836]

(25). Pauly JR; Marks MJ; Robinson SF; van de Kamp JL; Collins AC Chronic nicotine and mecamylamine treatment increase brain nicotinic receptor binding without changing $a 4$ or $\beta 2$ mRNA levels. J. Pharmacol. Exp. Ther. 1996, 278, 361-369. [PubMed: 8764371]

(26). Moretti M; Mugnaini M; Tessari M; Zoli M; Gaimarri A; Manfredi I; Pistillo F; Clementi F; Gotti C A comparative study of the effects of the intravenous self-administration or subcutaneous minipump infusion of nicotine on the expression of brain neuronal nicotinic receptor subtypes. Mol. Pharmacol. 2010, 78, 287-296. [PubMed: 20439469] 
(27). Hellström-Lindahl E; Mousavi M; Zhang X; Ravid R; Nordberg A Regional distribution of nicotinic receptor subunit mRNAs in human brain: comparison between Alzheimer and normal brain. Mol. Brain Res. 1999, 66, 94-103. [PubMed: 10095081]

(28). Mulcahy MJ; Lester HA Granulocytes as models for human protein marker identification following nicotine exposure. J. Neurochem. 2017, 142, 151-161. [PubMed: 28791704]

(29). Brody AL; Mukhin AG; La Charite J; Ta K; Farahi J; Sugar CA; Mamoun MS; Vellios E; Archie M; Kozman M; Phuong J; Arlorio F; Mandelkern MA Up-regulation of nicotinic acetylcholine receptors in menthol cigarette smokers. Int. J. Neuropsychopharm. 2013, 16, 957-966.

(30). Fan L; Balakrishna S; Jabba SV; Bonner PE; Taylor SR; Picciotto MR; Jordt SE Menthol decreases oral nicotine aversion in C57BL/6 mice through a TRPM8-dependent mechanism. Tobacco Control 2016, 25, ii50-ii54. [PubMed: 27698211]

(31). Galeotti N; Di Cesare Mannelli L; Mazzanti G; Bartolini A; Ghelardini C Menthol: a natural analgesic compound. Neurosci. Lett. 2002, 322, 145-148. [PubMed: 11897159]

(32). Macpherson LJ; Hwang SW; Miyamoto T; Dubin AE; Patapoutian A; Story GM More than cool: promiscuous relationships of menthol and other sensory compounds. Mol. Cell. Neurosci. 2006, 32, 335-343. [PubMed: 16829128]

(33). Karashima Y; Damann N; Prenen J; Talavera K; Segal A; Voets T; Nilius B Bimodal action of menthol on the transient receptor potential channel TRPA1. J. Neurosci. 2007, 27, 9874-9884. [PubMed: 17855602]

(34). Takaishi M; Uchida K; Suzuki Y; Matsui H; Shimada T; Fujita F; Tominaga M Reciprocal effects of capsaicin and menthol on thermosensation through regulated activities of TRPV1 and TRPM8. J. Physiol. Sci. 2016, 66, 143-155. [PubMed: 26645885]

(35). Xiao B; Dubin AE; Bursulaya B; Viswanath V; Jegla TJ; Patapoutian A Identification of transmembrane domain 5 as a critical molecular determinant of menthol sensitivity in mammalian TRPA1 channels. J. Neurosci. 2008, 28, 9640-9651. [PubMed: 18815250]

(36). Uhlen M; Fagerberg L; Hallstrom BM; Lindskog C; Oksvold P; Mardinoglu A; Sivertsson A; Kampf C; Sjostedt E; Asplund A; Olsson I; Edlund K; Lundberg E; Navani S; Szigyarto CA; Odeberg J; Djureinovic D; Takanen JO; Hober S; Alm T; Edqvist PH; Berling H; Tegel H; Mulder J; Rockberg J; Nilsson P; Schwenk JM; Hamsten M; von Feilitzen K; Forsberg M; Persson L; Johansson F; Zwahlen M; von Heijne G; Nielsen J; Ponten F Proteomics. Tissuebased map of the human proteome. Science 2015, 347, No. 1260419. [PubMed: 25613900]

(37). Voronova IP; Tuzhikova AA; Kozyreva TV Expression of Genes for Temperature-Sensitive TRP Channels in the Rat Hypothalamus in Normal Conditions and on Adaptation to Cold. Neurosci. Behav. Physiol. 2014, 44, 565-570.

(38). Hans M; Wilhelm M; Swandulla D Menthol suppresses nicotinic acetylcholine receptor functioning in sensory neurons via allosteric modulation. Chem. Senses 2012, 37, 463-469. [PubMed: 22281529]

(39). Henderson BJ; Grant S; Chu BW; Shahoei R; Huard SM; Saladi SSM; Tajkhorshid E; Dougherty DA; Lester HA Menthol Stereoisomers Exhibit Different Effects on $a 4 \beta 2 \mathrm{nAChR}$ Upregulation and Dopamine Neuron Spontaneous Firing. eNeuro 2018, 5, No. ENEURO.0465-18.2018.

(40). Sinha R Chronic stress, drug use, and vulnerability to addiction. Ann. N. Y. Acad. Sci. 2008, 1141, 105-130. [PubMed: 18991954]

(41). Rohleder N; Kirschbaum C The hypothalamic-pituitaryadrenal (HPA) axis in habitual smokers. Int. J. Psychophysiol. 2006, 59, 236-243. [PubMed: 16325948]

(42). al'Absi M Hypothalamic-pituitary-adrenocortical responses to psychological stress and risk for smoking relapse. Int. J. Psychophysiol. 2006, 59, 218-227. [PubMed: 16442170]

(43). Steptoe A; Ussher M Smoking, cortisol and nicotine. Int. J. Psychophysiol. 2006, 59, 228-235. [PubMed: 16337291]

(44). McKee SA; Sinha R; Weinberger AH; Sofuoglu M; Harrison EL; Lavery M; Wanzer J Stress decreases the ability to resist smoking and potentiates smoking intensity and reward. J. Psychopharmacol. 2011, 25, 490-502. [PubMed: 20817750]

(45). Paulo JA; Gaun A; Gygi SP Global Analysis of Protein Expression and Phosphorylation Levels in Nicotine-Treated Pancreatic Stellate Cells. J. Proteome Res. 2015, 14, 4246-4256. [PubMed: 26265067] 
(46). McClure-Begley TD; Esterlis I; Stone KL; Lam TT; Grady SR; Colangelo CM; Lindstrom JM; Marks MJ; Picciotto MR Evaluation of the Nicotinic Acetylcholine ReceptorAssociated Proteome at Baseline and Following Nicotine Exposure in Human and Mouse Cortex. eNeuro 2016, 3, No. ENEURO.0166-16.2016.

(47). Zhu B; Li X; Chen H; Wang H; Zhu X; Hou H; Hu Q iTRAQ proteomic analysis of the hippocampus in a rat model of nicotine-induced conditioned place preference. Biochem. Biophys. Res. Commun. 2017, 486, 971-977. [PubMed: 28359756]

(48). Paulo JA; Jedrychowski MP; Chouchani ET; Kazak L; Gygi SP Multiplexed Isobaric Tag-Based Profiling of Seven Murine Tissues Following In Vivo Nicotine Treatment Using a Minimalistic Proteomics Strategy. Proteomics 2018, 18, No. e1700326. [PubMed: 29660237]

(49). Itoi K; Jiang YQ; Iwasaki Y; Watson SJ Regulatory mechanisms of corticotropin-releasing hormone and vasopressin gene expression in the hypothalamus. J. Neuroendocrinol. 2004, 16, 348-355. [PubMed: 15089973]

(50). Tweed JO; Hsia SH; Lutfy K; Friedman TC The endocrine effects of nicotine and cigarette smoke. Trends Endocrinol. Metab. 2012, 23, 334-342. [PubMed: 22561025]

(51). Sullivan RM; Dufresne MM Mesocortical dopamine and HPA axis regulation: role of laterality and early environment. Brain Res. 2006, 1076, 49-59. [PubMed: 16483551]

(52). Levy BH; Tasker JG Synaptic regulation of the hypothalamic-pituitary-adrenal axis and its modulation by glucocorticoids and stress. Front. Cell. Neurosci. 2012, 6, No. 24. [PubMed: 22593735]

(53). Parker SL; Fu Y; McAllen K; Luo J; McIntosh JM; Lindstrom JM; Sharp BM Up-regulation of brain nicotinic acetylcholine receptors in the rat during long-term self-administration of nicotine: disproportionate increase of the a6 subunit. Mol. Pharmacol. 2004, 65, 611-622. [PubMed: 14978239]

(54). Wang J; Kim JM; Donovan DM; Becker KG; Li MD Significant modulation of mitochondrial electron transport system by nicotine in various rat brain regions. Mitochondrion 2009, 9, 186195. [PubMed: 19460297]

(55). Cormier A; Morin C; Zini R; Tillement JP; Lagrue G Nicotine protects rat brain mitochondria against experimental injuries. Neuropharmacology 2003, 44, 642-652. [PubMed: 12668050]

(56). Xie YX; Bezard E; Zhao BL Investigating the receptor-independent neuroprotective mechanisms of nicotine in mitochondria. J. Biol. Chem. 2005, 280, 32405-32412. [PubMed: 15985439]

(57). Lin AH; Liu MH; Ko HK; Perng DW; Lee TS; Kou YR Menthol Cigarette Smoke Induces More Severe Lung Inflammation Than Non-menthol Cigarette Smoke Does in Mice With Subchronic Exposure - Role of TRPM8. Front. Physiol. 2018, 9, No. 1817. [PubMed: 30618827]

(58). Nazıroğlu M; Blum W; Josvay K; Ć ,ĭ̆ B; Henzi T; Olah Z; Vizler C; Schwaller B; Pecze L Menthol evokes $\mathrm{Ca}(2+)$ signals and induces oxidative stress independently of the presence of TRPM8 (menthol) receptor in cancer cells. Redox Biol. 2018, 14, 439-449. [PubMed: 29078169]

(59). Drougard A; Fournel A; Valet P; Knauf C Impact of hypothalamic reactive oxygen species in the regulation of energy metabolism and food intake. Front. Neurosci. 2015, 9, No. 56. [PubMed: 25759638]

(60). Gyengesi E; Paxinos G; Andrews ZB Oxidative Stress in the Hypothalamus: the Importance of Calcium Signaling and Mitochondrial ROS in Body Weight Regulation. Curr. Neuropharmacol. 2012, 10, 344-353. [PubMed: 23730258]

(61). Spiers JG; Chen HJ; Sernia C; Lavidis NA Activation of the hypothalamic-pituitary-adrenal stress axis induces cellular oxidative stress. Front. Neurosci. 2014, 8, No. 456. [PubMed: 25646076]

(62). Smith SS; Fiore MC; Baker TB Smoking cessation in smokers who smoke menthol and nonmenthol cigarettes. Addiction 2014, 109, 2107-2117. [PubMed: 24938369]

(63). Lin AH; Liu MH; Ko HB; Perng DW; Lee TS; Kou YR Inflammatory Effects of Menthol vs. Non-menthol Cigarette Smoke Extract on Human Lung Epithelial Cells: A Double-Hit on TRPM8 by Reactive Oxygen Species and Menthol. Front. Physiol. 2017, 8, No. 263. [PubMed: 28496415]

(64). Talhout R; Schulz T; Florek E; van Benthem J; Wester P; Opperhuizen A Hazardous compounds in tobacco smoke. Int. J. Environ. Res. Public Health 2011, 8, 613-628. [PubMed: 21556207] 
(65). van de Nobelen S; Kienhuis AS; Talhout R An Inventory of Methods for the Assessment of Additive Increased Addictiveness of Tobacco Products. Nicotine Tob. Res. 2016, 18, 1546-1555. [PubMed: 26817491]

(66). Rabinoff M; Caskey N; Rissling A; Park C Pharmacological and chemical effects of cigarette additives. Am. J. Public Health 2007, 97, 1981-1991. [PubMed: 17666709]

(67). Ahijevych K; Garrett BE The role of menthol in cigarettes as a reinforcer of smoking behavior. Nicotine Tob. Res. 2010, 12, S110-S116. [PubMed: 21177367]

(68). Wickham RJ How Menthol Alters Tobacco-Smoking Behavior: A Biological Perspective. Yale $J$. Biol. Med. 2015, 88, 279-287. [PubMed: 26339211]

(69). Vizcaíno JA; Csordas A; del-Toro N; Dianes JA; Griss J; Lavidas I; Mayer G; Perez-Riverol Y; Reisinger F; Ternent T; Xu Q-W; Wang R; Hermjakob H 2016 update of the PRIDE database and its related tools. Nucleic Acids Res. 2016, 44, D447-D456. [PubMed: 26527722] 


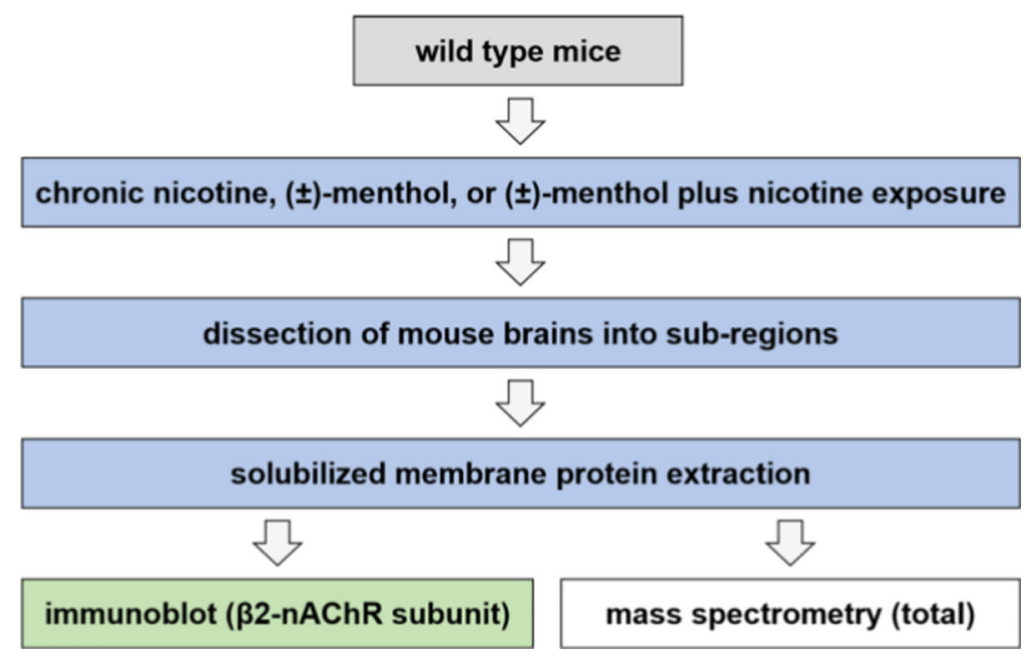

Figure 1.

Experimental design. Wild-type (WT) mice were chronically exposed to vehicle, nicotine, $( \pm)$-menthol, or $( \pm)$-menthol plus nicotine for 10-12 days using osmotic minipumps. Mice were euthanized, and their brains removed and dissected into subregions. Solubilized membrane protein extracts were prepared for each region. Protein extracts were then queried for changes in protein expression in response to drug treatments using immunoblotting ( $\beta 2$ subunit) or assessing total membrane protein level changes using mass spectrometry. 

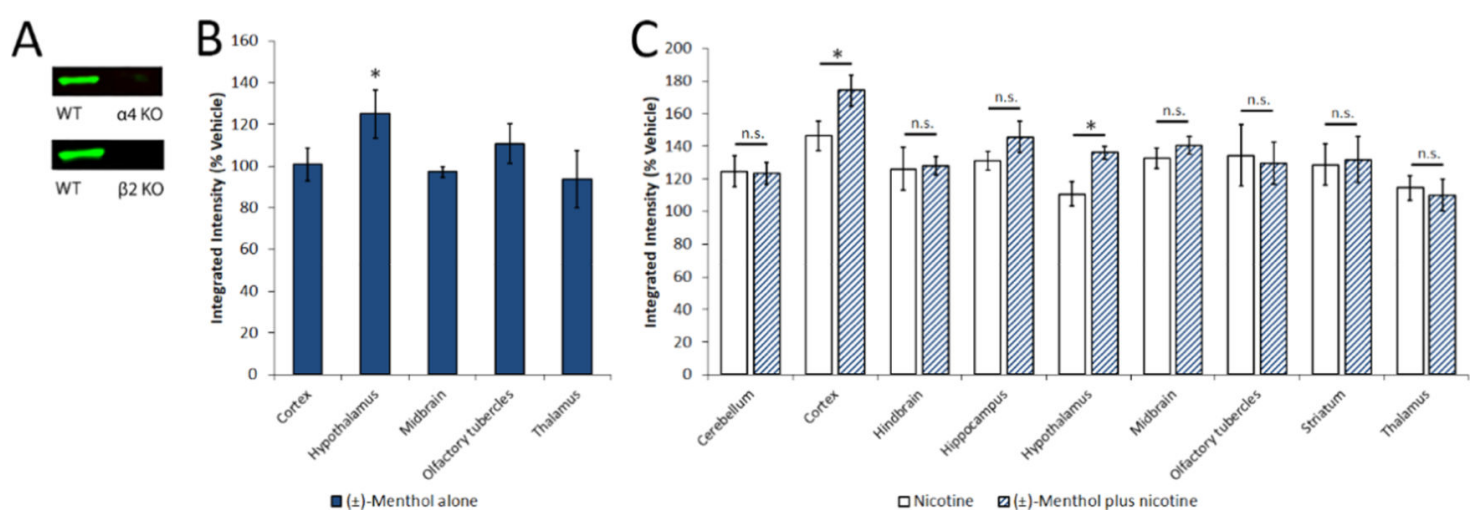

Figure 2.

(A) Immunoblotting confirmation of $\beta 2$ antibody specificity. To ascertain possible nonspecific signals using the selected $\beta 2 \mathrm{nAChR}$ antibody, wild-type whole brain samples were compared to both $\beta 2$ and $a 4$ knockout murine whole brain preparations. The band identified as $\beta 2(50 \mathrm{kDa})$ was absent in both $a 4$ and $\beta 2$ subunit knockouts. The cortex and hypothalamus both demonstrated an increase in the $\beta 2$ signal in ( \pm )-menthol plus nicotine $(\mathrm{M}+\mathrm{N})$ compared to nicotine alone $(\mathrm{N})$-treated tissues. Both $\mathrm{N}+\mathrm{M}$ and $\mathrm{N}$ were normalized to the vehicle (V)-treated tissues. (B) Effects of chronic ( \pm -menthol exposure on specific brain regions. Only the hypothalamus demonstrated increases in $\beta 2$ subunit expression when treated with $( \pm)$-menthol compared to the vehicle. Cortex $(n=8)$ and hypothalamus $(n=5)$; all other regions $(n=3)$. (C) Region-specific analysis of $\beta 2 \mathrm{nAChR}$ subunit expression between nicotine and $( \pm)$-menthol plus nicotine treatments. Only the cortex and hypothalamus show enhancement in $\beta 2$ subunit expression when treated with $( \pm)$ menthol plus nicotine compared to nicotine treatment alone. Cortex and midbrain $(n=7$ per treatment); all other regions $(n=6)$. Significance was determined using an unpaired Student's $t$-test. “*”: $p \leq 0.05$; “n.s.”: not significant. 
A

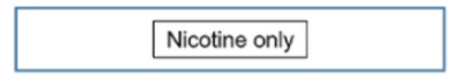

Vs.

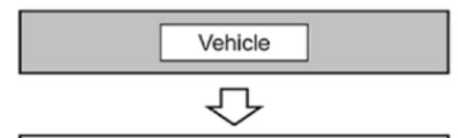

Nicotine altered proteins

C
B

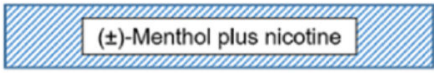

Vs.

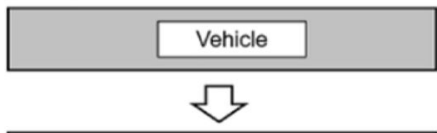

( \pm -Menthol plus nicotine altered proteins $A$<smiles>CC1CCCCC1</smiles>
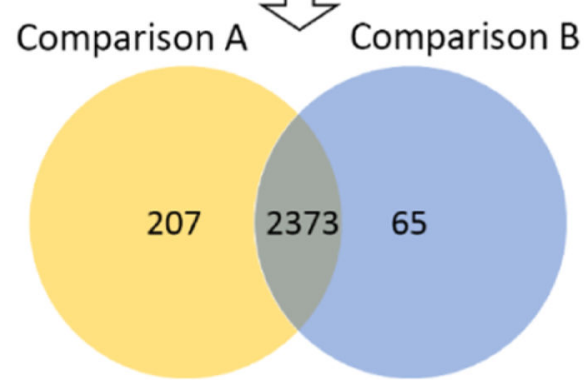

Figure 3.

Summary of treatment analyses. Vehicle-normalized hypothalamic membrane protein level changes following (A) chronic nicotine alone and (B) ( \pm )-menthol plus nicotine were compared using mass spectrometry. (C) Comparison A identified which proteins were upregulated and comparison $\mathrm{B}$ identified which proteins were downregulated in response to $( \pm)$-menthol plus nicotine exposure versus nicotine alone exposure. 


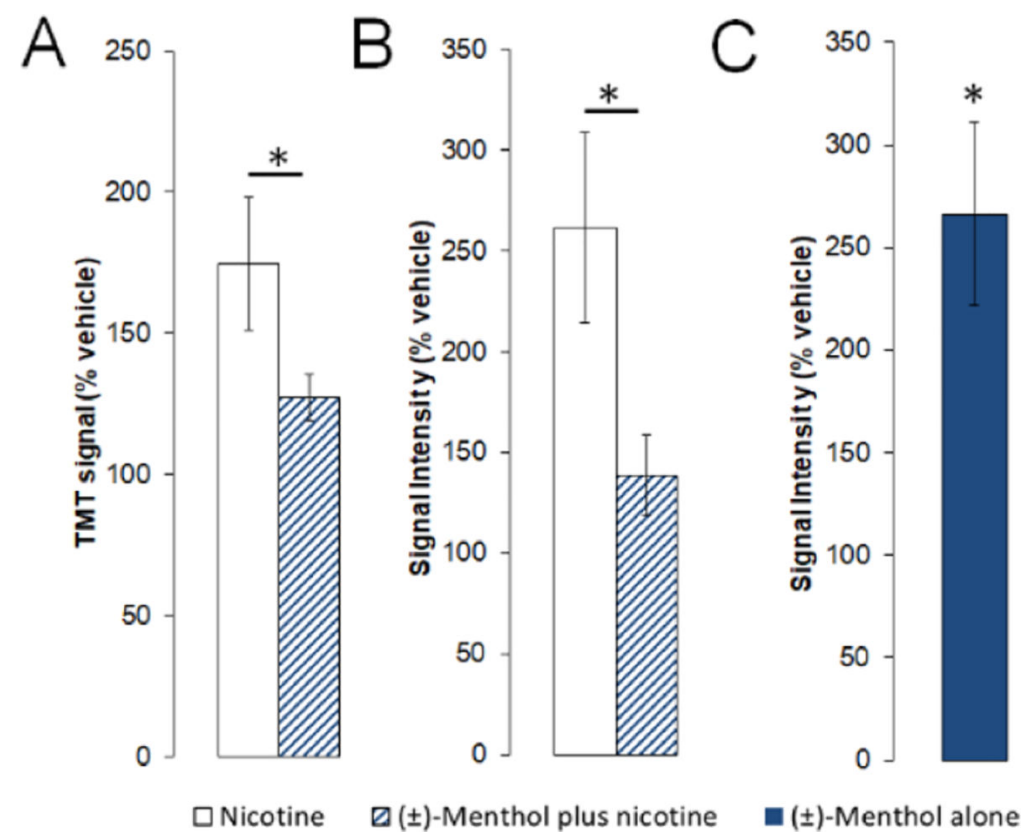

Figure 4.

Immunoblot validation of ndufa1, a potential biomarker for menthol exposure. Nine of the 18 samples [three control, three nicotine-treated, and three ( \pm )-menthol plus nicotine] measured by mass spectrometry were selected to validate changes in ndufal with immunoblots. (A) The observed mass spectrometry signal and (B) immunoblot validation. (C) Changes in response to $( \pm)$-menthol alone were also investigated. Ndufa1 was validated with two immunoblots, each blot measuring three biological replicates for each treatment group. Each biological replicate was measured in duplicate in each blot. Control samples were pooled and loaded in duplicate. 


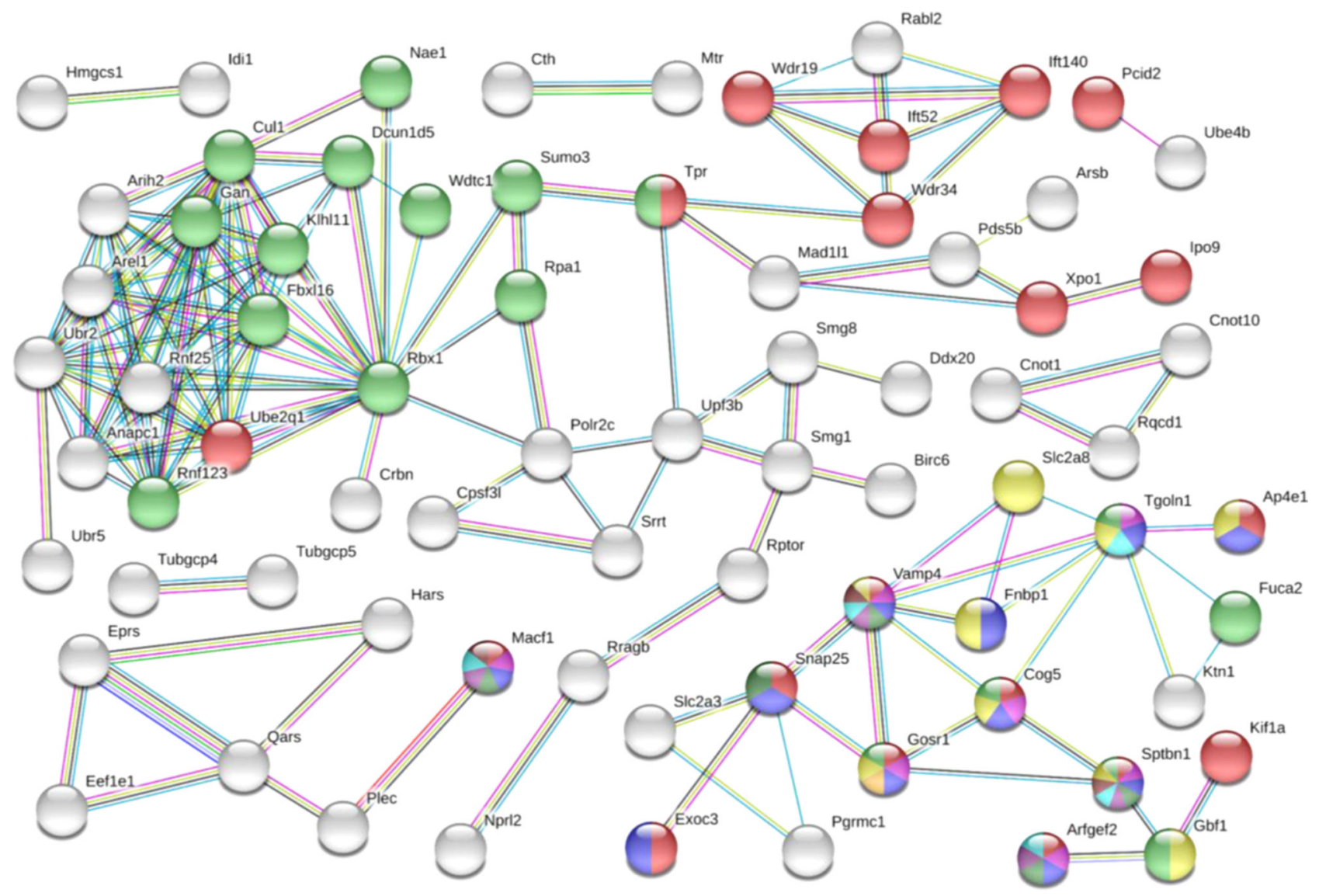

Figure 5.

: STRING analysis of proteins upregulated after ( \pm )-menthol plus nicotine compared to nicotine alone. Enrichment for the following biological processes was observed: protein transport (red, GO:0015031, 36 proteins, FDR $=1.39 \times 10^{-7}$ ); vesicle-mediated transport (blue, GO:0016192, 28 proteins, FDR $=7.31 \times 10^{-5}$ ); Golgi vesicle transport (purple, GO:0048193, 14 proteins, FDR $=3.66 \times 10^{-6}$ ); vesicle-mediated transport to the plasma membrane (dark green, GO:0098876, 6 proteins, FDR $=0.0033$ ); post-Golgi vesiclemediated transport (teal, GO:0006892, 6 proteins, FDR $=0.0064$ ); Golgi to plasma membrane protein transport (brown, GO:0043001, 4 proteins, FDR $=0.0085$ ); Golgi to plasma membrane transport GO: BP (dark purple, GO:0006893, 5 proteins, FDR $=0.0038$ ). Enrichment for Reactome pathways post-translational protein modification (green, MMU-597592, 25 proteins, FDR $=0.0217$ ) and membrane trafficking (yellow, MMU-199991, 20 proteins, FDR $=9.47 \times 10^{-5}$ ) was also observed. 


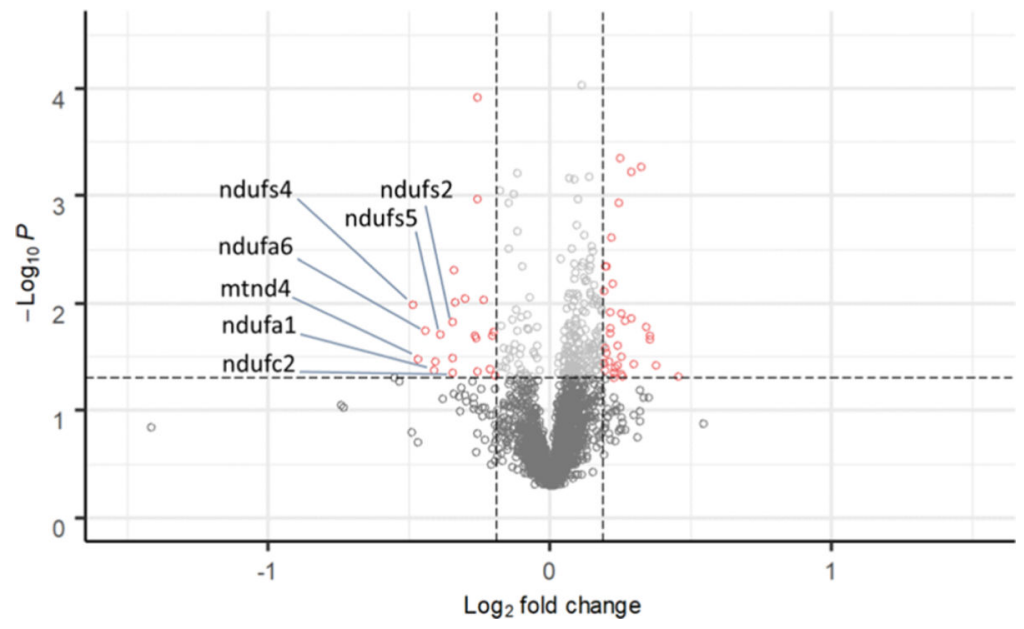

Figure 6.

Volcano plot of all proteins identified in ( \pm )-menthol plus nicotine samples. 2645 proteins were identified in five of six or six of six ( \pm )-menthol plus nicotine samples. Proteins meeting inclusion criteria are shown in red. The seven members of the mitochondrial electron-transport chain complex 1 downregulated after $( \pm)$-menthol plus nicotine exposure are labeled. 


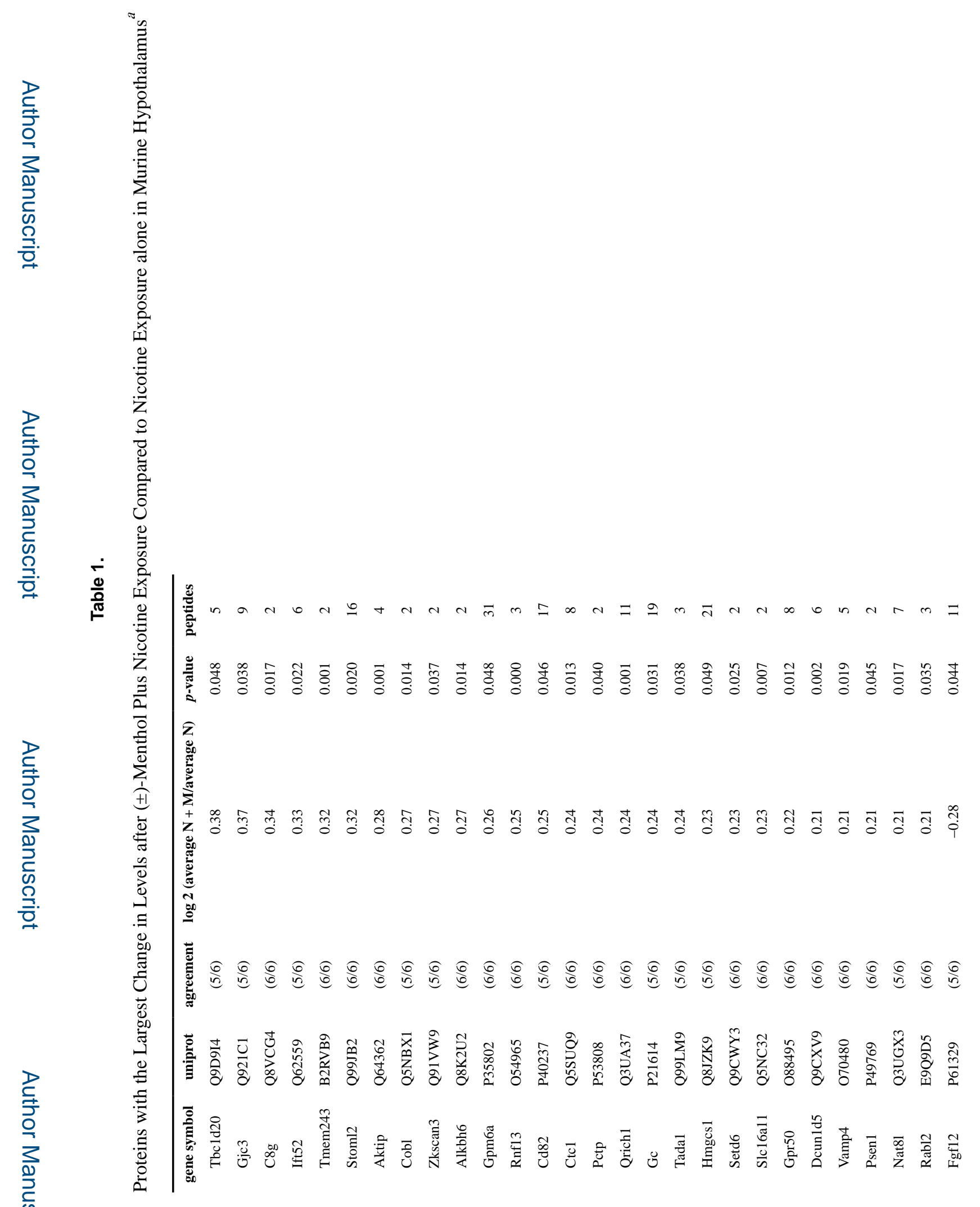


خ

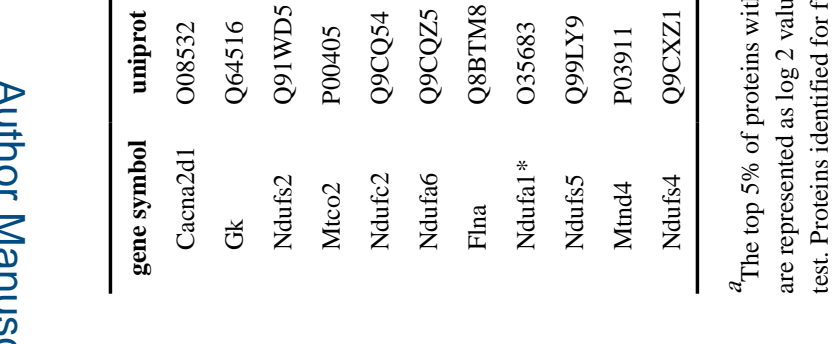

훔. 
Table 2.

Known Non-nAChR Targets or Potential Targets for Menthol ${ }^{a}$

\begin{tabular}{ccc}
\hline gene symbol & $\log \mathbf{2}$ (average $\mathbf{N}+\mathbf{M} /$ average $\mathbf{N})$ & $\boldsymbol{p}$-value \\
Gabra1 & -0.06 & 0.29 \\
Gabrb1 & -0.08 & 0.23 \\
Gabrg2 & -0.16 & 0.04 \\
Gabrg3 & 0.08 & 0.30 \\
Oprk1 & -0.03 & 0.37 \\
Trpm3 & -0.08 & 0.24 \\
Trpv2 & -0.33 & 0.02 \\
\hline
\end{tabular}

${ }^{a}$ Seven proteins that are affected by menthol exposure or are possible targets for menthol were identified in the hypothalamus. Average vehiclenormalized $\log 2$ values are shown. Significance was determined using an unpaired Student's $t$-test. 
Table 3.

Selected Pathways Enriched in Response to Chronic Nicotine Exposure in the Hypothalamus ${ }^{a}$

\begin{tabular}{llllc}
\hline \multicolumn{1}{c}{ description } & database & \multicolumn{1}{c}{ ID } & no. of proteins & FDR \\
post-translational protein modification & reactome & MMU-597592 & 97 & 0.00077 \\
vesicle-mediated transport & reactome & MMU-5653656 & 60 & $1.25 \times 10^{-05}$ \\
intra-Golgi and retrograde Golgi-to-ER traffic & reactome & MMU-6811442 & 22 & 0.0092 \\
transport to the Golgi and subsequent modification & reactome & MMU-948021 & 20 & 0.0174 \\
protein processing in the endoplasmic reticulum & KEGG & mmu04141 & 20 & 0.0072 \\
ER to Golgi Anterograde Transport & reactome & MMU-199977 & 17 & 0.0311 \\
clathrin-mediated endocytosis & reactome & MMU-8856828 & 15 & 0.0251 \\
intra-Golgi traffic & reactome & MMU-6811438 & 9 & 0.0106 \\
SNARE interactions in vesicular transport & KEGG & mmu04130 & 7 & 0.0297 \\
\hline
\end{tabular}

a Selected enriched pathways associated with protein expression. Pathway descriptions were provided by either reactome pathway analysis or Kyoto Encyclopedia of Genes and Genomes (KEGG) pathway analysis database. The pathway ID, number of proteins represented in each pathway, and the false discovery rate (FDR) for enrichment are provided. 